\title{
Effects of cow, goat, and buffalo milk on the characteristics of cream cheese with whey retention
}

\author{
Michele FANGMEIER ${ }^{1}$, Grasciele Tamara KEMERICH ${ }^{1}$, Bruna Lenhardt MACHADO ${ }^{1}$, Mônica Jachetti MACIEL ${ }^{1}$, \\ Claucia Fernanda Volken de Souza ${ }^{1 \star}$
}

\begin{abstract}
Although cow milk is the most widely used dairy product, the milk of other animals presents characteristics relevant to the development of these products. Goat milk has higher digestibility and a lower incidence of allergic reactions than cow milk, while buffalo milk has higher levels of lipids, proteins and lactose. The objective of this work was to elaborate and evaluate the physicochemical, technological, microbiological and sensory characteristics of cream cheese formulations elaborated with different proportions of cow, goat and buffalo milk without whey removal. The milk mixture was allowed to produce cream cheese with high levels of ashes and proteins, and despite the retention of the whey, no occurrence of syneresis was observed in the formulations. The formulation elaborated with $33.33 \%$ of each type of milk obtained the highest positive intent to purchase, the highest acceptability index for overall impression and the highest score for the flavor attribute. Considering the number of probiotic microorganisms present in the cream cheese composition, the developed product can be considered a functional food. It is possible to prepare cream cheese with different types of milk and whey retention, creating a competitive product for the market and an alternative for the industry.
\end{abstract}

Keywords: cheese whey; physicochemical quality; sensory analysis; technological characteristics; microbiological analyses.

Practical Application: Cream cheese with whey retention: differentiated product with environmental sustainability.

\section{Introduction}

Milk, according to the Food and Drug Administration (2017a, b), is milk secretion obtained from one or more healthy milk-producing animals, such as cow, goat, sheep and buffalo. Goat and cow milk are different in terms of their constituents; the former has higher amounts of casein, medium-chain fatty acids, polyunsaturated fatty acids, conjugated linoleic acid, calcium, phosphorus, magnesium and copper (Ceballos et al., 2009). Buffalo milk has higher levels of lipids, proteins and lactose than cow milk (Zicarelli, 2004; Guo et al., 2007). Mahmood \& Usman (2010) compared physicochemical parameters, such as $\mathrm{pH}$, specific gravity, titratable acidity, total solids, ash, lipids, proteins and lactose from buffalo, cow, goat and sheep milk samples and found that all the parameters analyzed were higher in buffalo and sheep milk than in cow and goat milk.

The elaboration of products with different types of milk was explored by Garcia et al. (2008), who carried out sensorial evaluation of rennet cheese with cow milk, goat milk and buffalo milk, and all the cheeses presented good acceptability indices for the evaluated attributes, except for the taste and aroma of goat milk cheese. Queiroga et al. (2013) observed that rennet cheese made from the goat and cow milk mixture is a differentiated product with a less pronounced goat flavor, which has contributed to consumer acceptance while maintaining the positive nutritional properties of goat cheese.

Cream cheese is a fresh, soft curd cheese of pasty consistency, whose emulsion is formed by lipids, milk and water, acidified by lactic acid bacteria (Phadungath, 2005). Its manufacturing process normally has a whey removal step, resulting in a yellow cheese by-product called whey, due to the presence of riboflavin (vitamin B2) (De Wit, 2001). Cheese whey has pollution potential, as it presents a biochemical oxygen demand of $30-50 \mathrm{~kg} / \mathrm{m}^{3}$ and chemical oxygen demand of $60-80 \mathrm{~kg} / \mathrm{m}^{3}$, mineral salts at concentrations of $0.46-10 \%$ (Venetsaneas et al., 2009), nitrogen at $0.2-1.76 \mathrm{~kg} / \mathrm{m}^{3}$ and phosphorus at $0.12-0.54 \mathrm{~kg} / \mathrm{m}^{3}$, causing eutrophication (Appels et al., 2008). On the other hand, whey is composed of nutrients such as lactose $(4.5-5 \% \mathrm{w} / \mathrm{v})$, soluble proteins $(0.6-0.8 \% \mathrm{w} / \mathrm{v})$ and lipids $(0.4-0.5 \% \mathrm{w} / \mathrm{v})$, as well as lactic acid $(0.05 \% \mathrm{w} / \mathrm{v})$ and B vitamins (Blaschek et al., 2007).

In light of the different compositions of cow, goat and buffalo milk and the nutritional importance and environmental problems of whey, the purpose of this study was to elaborate and evaluate the physicochemical, technological, microbiological and sensory characteristics of cream cheese with different concentrations of cow, goat and buffalo milk, with retention of the whey in the coagulation step. 


\section{Materials and methods}

\subsection{Cream cheese material and preparation}

A simplex-centroid design for mixtures (Montgomery, 2001) was used to evaluate the effect of the proportion of cow $\left(\mathrm{X}_{1}\right)$, goat $\left(\mathrm{X}_{2}\right)$, and buffalo $\left(\mathrm{X}_{3}\right)$ milk on the characteristics of cream cheese. Table 1 shows the experimental design, in which the proportions of the components are expressed as fractions of the total mixture. Seven cream cheese formulations with different proportions of cow, goat, and buffalo milk, previously subjected to the slow pasteurization process $\left(63^{\circ} \mathrm{C} / 30 \mathrm{~min}\right)$, were prepared according to Table 1 . The milk was acquired from dairy industries located in the region.

The seven formulations were prepared on the same day, and three batches of each were made, totaling 21 samples. The amount of each ingredient used in the elaboration of cream cheese was calculated based on the use of 1,500 $\mathrm{g}$ of milk (cow, goat, or buffalo). To the milk, $69.65 \%$ (w/w) heavy cream $(49.00 \%$ fat, Languiru, Teutônia, RS) and 26.12\% (w/w) whole milk powder (Languiru, Teutônia, RS) were added, based on previous experiments. The mixtures were heated up to $42-43{ }^{\circ} \mathrm{C}$; subsequently, $0.02 \%$ (w/w) of dairy culture (BioRich ${ }^{\circledR}$, Chr. Hansen, Denmark) containing the microorganisms Lactobacillus acidophilus, Bifidobacterium lactis and Streptococcus thermophilus and $0.03 \%$ (w/w) calcium chloride $\left(\right.$ Nuclear $^{\circledR}$, Diadema, SP) were added. After manual homogenization for $3 \mathrm{~min}$, the blends were placed in a fermentation chamber at $40{ }^{\circ} \mathrm{C}$ until the $\mathrm{pH}$ reached 4.8 . Then, $0.09 \%(w / w)$ potassium sorbate (VETEC, Rio de Janeiro, RJ), $1.74 \%(w / w)$ xanthan gum (Delaware ${ }^{\circledR}$, Porto Alegre, RS), $1.74 \%(w / w)$ guar gum (Salsul ${ }^{\circledR}$, Rio Grande, RS) and $0.61 \%$ (w/w) sodium chloride (Salsul ${ }^{\circledR}$, Rio Grande, RS) were added. Homogenization was performed in an industrial blender at high speed for approximately $3 \mathrm{~min}$. The product was packed in plastic containers, covered with aluminum foil and stored in a refrigerator at $5^{\circ} \mathrm{C}$.

\subsection{Physicochemical and technological analyses}

The cow, goat, and buffalo milk samples were analyzed in triplicate before use. The cream cheese formulations were also evaluated in triplicate for each batch produced at 1 and 28 days after manufacture. The methods used were those of the Normative Instruction (Instrução Normativa - IN) no. 68/2006 of the Ministry

Table 1. Cream cheese formulations with different proportions of cow, goat and buffalo milk.

\begin{tabular}{ccccc}
\hline \multirow{2}{*}{ Samples } & \multirow{2}{*}{$\begin{array}{c}\text { Proportion } \\
\text { of variables }\end{array}$} & \multicolumn{3}{c}{ Amount $(\%)$} \\
\cline { 3 - 5 }$\left(\mathrm{X}_{1}, \mathrm{X}_{2}, \mathrm{X}_{3}\right)$ & Cow $\left(\mathrm{X}_{1}\right)$ & Goat $\left(\mathrm{X}_{2}\right)$ & Buffalo $\left(\mathrm{X}_{3}\right)$ \\
\hline CC1 & $(1,0,0)$ & 100.00 & 0.00 & 0.00 \\
CC2 & $(0,1,0)$ & 0.00 & 100.00 & 0.00 \\
CC3 & $(0,0,1)$ & 0.00 & 0.00 & 100.00 \\
CC4 & $(1 / 2,1 / 2,0)$ & 50.00 & 50.00 & 0.00 \\
CC5 & $(1 / 2,0,1 / 2)$ & 50.00 & 0.00 & 50.00 \\
CC6 & $(0,1 / 2,1 / 2)$ & 0.00 & 50.00 & 50.00 \\
CC7 & $(1 / 3,1 / 3,1 / 3)$ & 33.33 & 33.33 & 33.33 \\
\hline
\end{tabular}

of Agriculture, Livestock and Supply (Ministério da Agricultura, Pecuária e Abastecimento - MAPA) (Brasil, 2006): pH, lipid content, protein content, lactose content, titratable acidity and water activity. Moisture and ash contents were evaluated based on the method of the Adolfo Lutz Institute (Instituto Adolfo Lutz, 2008). The syneresis index was evaluated according to a method adapted from Aichinger et al. (2003), subjecting $15 \mathrm{~g}$ of refrigerated sample $\left(4{ }^{\circ} \mathrm{C}\right)$ to centrifugation $(5000 \mathrm{rpm})$ for $60 \mathrm{~min}$ and three additional sequences of $30 \mathrm{~min}$ with pauses; the syneresis percentage was calculated by the ratio of the mass of the separated whey to the initial mass of the sample, multiplied by 100 . The $\mathrm{pH}$ variation throughout the process was evaluated with $\mathrm{pH}$ measurements at time 0 and every 30 min until the cut-off point ( $\mathrm{pH} 4.8$ ) in the seven cream cheese formulations. $\mathrm{V}_{\text {max }}$ (maximum time of acidification, measured in units of $\mathrm{pH}$ per minute (upH.min ${ }^{-1}$ )), $\mathrm{T} \mathrm{V}_{\max }$ (time (in hours) to reach the maximum rate of acidification) and $\mathrm{pH} \mathrm{V}_{\max }\left(\mathrm{pH}\right.$ corresponding to $\mathrm{V}_{\max }$ ) were considered the kinetic parameters. The color analysis was performed on a colorimeter (Konica Minolta, CM-5) using the color parameters " $\mathrm{L}$ ” ranging from 0 (black) to 100 (white), “+ a" (red) to "-a" (green) and "+ b" (yellow) to "-b" (blue) (Commission Internationale de l'Eclairage, 1996). The texture of the formulations was determined by the texture analyzer (Model TA-TX) within 1 day of production, based on the method described by Miri \& Habibi Najafi (2011), with some modifications. A flat rod probe was attached to a $10 \mathrm{~g}$ compression load with a target value of $10 \mathrm{~mm}$, speed $5 \mathrm{~cm} \cdot \mathrm{min}^{-1}$ and cylindrical probe set to penetrate the samples to a depth of $0.8 \mathrm{~cm}$.

\subsection{Microbiological analyses}

Microbiological analyses for the quantification of lactic acid bacteria were performed using a method adapted from Vinderola \& Reinheimer (1999) at 1, 14, and 28 days after manufacture, in triplicate for each batch produced. The microorganisms were quantified by the depth seeding technique. For Lactobacillus acidophilus, in anaerobiosis for $72 \mathrm{~h}$ at $37^{\circ} \mathrm{C}$, MRS Bile agar (0.15\%) was used (Man, Rogosa \& Sharpe); for Bifidobacterium lactis, an overlay was added to the plate, which was incubated in anaerobiosis for $72 \mathrm{~h}$ at $37^{\circ} \mathrm{C}$ using MRS agar with sodium propionate $(0.3 \%)$ and lithium chloride (0.2\%); and for Streptococcus thermophilus, in aerobiosis for $48 \mathrm{~h}$ at $37^{\circ} \mathrm{C}, \mathrm{M} 17$ agar was used.

\subsection{Sensory analysis}

Sensory analysis of cream cheese formulations at 1 day after manufacture was performed with a team of 50 untrained tasters, who evaluated the appearance, odor, flavor, texture and overall impression of the product through a structured scale of nine points, ranging from 1, "I disliked it very much," to 9, "I liked it very much" (Minim, 2012). Only the tasters who signed the Free and Informed Consent Form, approved by the Research Ethics Committee of the University of Vale do Taquari (Universidade do Vale do Taquari - Univates), under the approval no. 997.293 and CAAE no. 42685515.8.0000.5310, were included in this analysis. The acceptability index (AI) was calculated by means of the mathematical expression $\mathrm{AI}(\%)=\mathrm{A} \times 100 / \mathrm{B}$, where $\mathrm{A}$ is the mean score obtained for the product and $B$ is the maximum score given to the product. The tasters were also asked about 
their intent to purchase each sample, ranging from 1, "I certainly would not buy," to 5, "I would certainly buy" (Dutcosky, 1996).

\subsection{Statistical analysis}

The results of the physicochemical and sensory analyses of cream cheese, as well as the physicochemical properties of the milk, were evaluated by analysis of variance (ANOVA), and the significance of the models was assessed by the F test. In the significant models, the means were compared using the Tukey test at the 5\% level of significance. Statistical calculations were performed using Statistica ${ }^{\circledR}$ software version 13.0.

\section{Results and discussion}

\subsection{Physicochemical characteristics of milk from different origins}

Table 2 presents the physicochemical characterization of cow, goat, and buffalo milk.

The lipid, protein, ash, and lactose contents were all significantly different between cow, goat, and buffalo milk $(\mathrm{p}<0.05)$ (Table 2). Protein, lipid, and lactose contents for buffalo milk were close to the maximum levels of 4.19, 5.34 and 5.33\%, respectively, presented in the review by Barlowska et al. (2011). The lactose content $(5.50 \% \mathrm{w} / \mathrm{w})$ observed for buffalo milk was close to the $5.52 \%(\mathrm{w} / \mathrm{w})$ found by Coelho et al. (2004) for the same milk. The protein content of goat milk $(3.24 \% \mathrm{w} / \mathrm{w})$ was also in agreement with the $3.2-4.3 \%(\mathrm{w} / \mathrm{w})$ and $3.15 \%(\mathrm{w} / \mathrm{w})$ observed by D'Alessandro (1991) and Mahmood \& Usman (2010), respectively, for the same milk. The color parameter $\mathrm{L}^{*}$ indicated a more pronounced tendency for white color in goat and buffalo milk compared to cow milk due to the low concentration of $\beta$-carotene, which expresses an orangey color (Pellegrini et al., 2012).

Due to the high protein content, including casein, and the amount of lipids, buffalo milk is a good raw material for processing, especially for cheese. Its $4 \%$ casein concentration is almost half those of cow milk (2.46 to 2.80\%) (Zicarelli, 2004; Guo et al., 2007) and goat milk (2.81\%) (Leitner et al., 2004).

Table 2. Characterization of the milk of different origins used for the elaboration of cream cheese formulations.

\begin{tabular}{lrrr}
\hline \multicolumn{1}{c}{ Analysis } & \multicolumn{1}{c}{ Cow milk } & Goat cheese & \multicolumn{1}{c}{ Buffalo milk } \\
\hline Lipids (\%) & $3.80 \pm 0.01^{\mathrm{c}}$ & $4.00 \pm 0.06^{\mathrm{b}}$ & $5.60 \pm 0.00^{\mathrm{a}}$ \\
Proteins (\%) & $3.39 \pm 0.01^{\mathrm{b}}$ & $3.24 \pm 0.00^{\mathrm{c}}$ & $4.30 \pm 0.01^{\mathrm{a}}$ \\
Ashes (\%) & $0.75 \pm 0.01^{\mathrm{c}}$ & $0.81 \pm 0.01^{\mathrm{b}}$ & $0.95 \pm 0.01^{\mathrm{a}}$ \\
Moisture (\%) & $88.06 \pm 0.01^{\mathrm{b}}$ & $88.06 \pm 0.00^{\mathrm{b}}$ & $88.09 \pm 0.01^{\mathrm{a}}$ \\
Acidity (\% lactic acid) & $14.00 \pm 0.06^{\mathrm{b}}$ & $14.20 \pm 0.06^{\mathrm{b}}$ & $14.50 \pm 0.06^{\mathrm{a}}$ \\
Lactose (\%) & $3.83 \pm 0.01^{\mathrm{c}}$ & $4.46 \pm 0.01^{\mathrm{b}}$ & $5.50 \pm 0.01^{\mathrm{a}}$ \\
pH & $6.86 \pm 0.00^{\mathrm{a}}$ & $6.70 \pm 0.00^{\mathrm{a}}$ & $6.88 \pm 0.00^{\mathrm{a}}$ \\
Color L $^{*}$ & $86.31 \pm 0.13^{\mathrm{b}}$ & $89.94 \pm 0.17^{\mathrm{a}}$ & $89.35 \pm 0.19^{\mathrm{a}}$ \\
Color a $^{*}$ & $-1.87 \pm 0.03^{\mathrm{b}}$ & $-2.61 \pm 0.03^{\mathrm{a}}$ & $-2.34 \pm 0.01^{\mathrm{a}}$ \\
Color b $^{*}$ & $10.72 \pm 0.08^{\mathrm{b}}$ & $9.09 \pm 0.04^{\mathrm{c}}$ & $11.38 \pm 0.04^{\mathrm{a}}$ \\
\hline
\end{tabular}

The results are expressed as the mean of the triplicates \pm standard deviation. Results in the same row with different superscript letters differ significantly ( $\mathrm{p} \leq 0.05)$ according to Tukey's test.
The low $\alpha_{\mathrm{S} 1}$-casein content of goat milk makes it less likely to cause an allergic reaction (Ramunno et al., 2001), since, according to Lara-Villoslada et al. (2005), the lower portion of $\alpha_{\mathrm{S1}}$-casein reduces sensitivity to the other allergenic protein, $\beta$-lactoglobulin, which resists hydrolysis by gastric pepsin.

\subsection{Physicochemical and technological characteristics of cream cheese formulations}

The physicochemical parameters of the cream cheese samples are shown in Table 3.

The lipid contents of the cream cheese samples on the first day of storage ranged from 24.31 to $28.05 \%$ (w/w). Among the formulations made exclusively with one type of milk, sample CC3 (buffalo milk) had the highest lipid content, which resulted from the fact that its milk had a higher lipid concentration than goat and cow milk ( 40 and $47 \%$ higher, respectively) (Table 2). The ash content ranged from 1.61 to $1.87 \%(\mathrm{w} / \mathrm{w})$, with a significant difference between most pairs of formulations. According to Table 2, buffalo milk had the highest ash content $(0.95 \% \mathrm{w} / \mathrm{w})$, so formulations CC3 and CC7 had the highest ash contents, 1.79 and $1.87 \%(\mathrm{w} / \mathrm{w})$, respectively. The minimum contents of total casein, $\alpha_{\mathrm{s} 2}$-casein, and $\mathrm{k}$-casein in buffalo milk are higher than those in cow milk and goat milk (Claeys et al., 2014); it is likely that this protein composition in buffalo milk may have favored the retention of fats and ash in the protein coagulation process during the preparation of samples CC 3 and CC7.

The moisture contents varied from 54.92 to $60.05 \%(\mathrm{w} / \mathrm{w})$, and samples with a high lipid content had a lower moisture content, which was also reported by Souza et al. (2012) for petit Suisse cheese elaborated with whey retention because lipids retain less water in the product.

The acidity increased three-fold over the 28-day storage period. The increase in acidity is a natural process caused by the lactic acid bacteria present in the product, due to the organic acids, mainly lactic acid, resulting from lactose fermentation by the added lactic acid culture (Buriti et al., 2005).

Protein contents for the cream cheese samples ranged from 5.70 to $7.00 \%(\mathrm{w} / \mathrm{w})$. The formulation produced exclusively with buffalo milk had the highest protein concentration, due to the higher protein content in its milk (Table 2).

On the first day of storage, the water activity values ranged between 0.90 and 0.95 . After 28 days, the water activity values ranged between 0.90 and 0.94 . According to Vinderola et al. (2000), in addition to factors such as low fermentation temperatures and $\mathrm{pH}$, high water activity favors microbial viability during the elaboration or storage of the product.

The color parameter $\mathrm{L}^{*}$ ranged from 88.13 to 89.90 , and it decreased over the storage period. According to Álvarez et al. (2007), the internal and external lightness $\mathrm{L}^{*}$ decreases with maturation and time. Formulation CC1 (cow milk) presented a higher value for the color parameter $\mathrm{b}^{*}$ compared to formulation CC2 (goat milk); this occurred because it has a higher concentration of lipids. 
Table 3. Physicochemical characterization of cream cheese samples with milk of different origins at 1 and 28 days after manufacture.

\begin{tabular}{|c|c|c|c|c|c|c|c|c|}
\hline \multirow{2}{*}{ Variables } & \multirow{2}{*}{ Days } & \multicolumn{7}{|c|}{ Formulations } \\
\hline & & $\mathrm{CC} 1$ & $\mathrm{CC} 2$ & CC3 & $\mathrm{CC} 4$ & CC5 & CC6 & CC7 \\
\hline Moisture (\% w/w) & 28 & $58.11 \pm 0.02^{c}$ & $57.71 \pm 0.01^{\mathrm{d}}$ & $56.62 \pm 0.03^{e}$ & $58.80 \pm 0.01^{\mathrm{b}}$ & $56.94 \pm 0.04^{\mathrm{f}}$ & $59.80 \pm 0.03^{\mathrm{a}}$ & $55.57 \pm 0.03^{g}$ \\
\hline Lipids (\% w/w) & 28 & $23.56 \pm 0.11^{\mathrm{e}}$ & $23.36 \pm 0.20^{\mathrm{e}}$ & $25.77 \pm 0.29^{b}$ & $25.30 \pm 0.45^{c}$ & $24.83 \pm 0.29^{\mathrm{d}}$ & $23.65 \pm 0.14^{\mathrm{e}}$ & $27.76 \pm 0.21^{\mathrm{a}}$ \\
\hline Ashes (\% w/w) & 1 & $1.61 \pm 0.01$ & $1.75 \pm 0.00^{c}$ & $1.79 \pm 0.00^{\mathrm{b}}$ & $1.70 \pm 0.02^{\mathrm{d}}$ & $1.62 \pm 0.00^{\mathrm{e}}$ & $1.69 \pm 0.00^{\mathrm{d}}$ & $1.87 \pm 0.00^{\mathrm{a}}$ \\
\hline Acidity $\left(\% \mathrm{C}_{3} \mathrm{H}_{6} \mathrm{O}_{3}\right)$ & 28 & $0.90 \pm 0.01^{\mathrm{c}}$ & $0.95 \pm 0.01^{\mathrm{b}}$ & $0.84 \pm 0.01^{\mathrm{d}}$ & $1.04 \pm 0.00^{\mathrm{a}}$ & $0.79 \pm 0.01^{\mathrm{e}}$ & $0.77 \pm 0.00^{\mathrm{f}}$ & $0.74 \pm 0.01^{g}$ \\
\hline \multirow[t]{2}{*}{ Proteins (\% w/w) } & 1 & $6.62 \pm 0.11^{\mathrm{ab}}$ & $6.47 \pm 0.03^{b}$ & $7.00 \pm 0.09^{\mathrm{a}}$ & $5.70 \pm 0.08^{c}$ & $6.49 \pm 0.23^{b}$ & $6.36 \pm 0.02^{\mathrm{b}}$ & $6.77 \pm 0.14^{\mathrm{ab}}$ \\
\hline & 28 & $6.56 \pm 0.05^{\mathrm{d}}$ & $6.77 \pm 0.01^{\mathrm{c}}$ & $7.30 \pm 0.09^{\mathrm{a}}$ & $6.83 \pm 0.04^{c}$ & $6.99 \pm 0.01^{\mathrm{b}}$ & $6.66 \pm 0.01^{\mathrm{cd}}$ & $6.68 \pm 0.07^{\mathrm{cd}}$ \\
\hline \multirow[t]{2}{*}{ Water activity } & 1 & $0.935 \pm 0.004^{\mathrm{e}}$ & $0.937 \pm 0.001^{\mathrm{d}}$ & $0.951 \pm 0.003^{\mathrm{a}}$ & $0.946 \pm 0.001^{\mathrm{b}}$ & $0.941 \pm 0.003^{c}$ & $0.946 \pm 0.004^{b}$ & $0.945 \pm 0.003^{\mathrm{b}}$ \\
\hline & 28 & $0.926 \pm 0.002^{\mathrm{d}}$ & $0.943 \pm 0.001^{\mathrm{a}}$ & $0.937 \pm 0.001^{\mathrm{b}}$ & $0.935 \pm 0.001^{c}$ & $0.918 \pm 0.001^{\mathrm{e}}$ & $0.926 \pm 0.001^{\mathrm{d}}$ & $0.935 \pm 0.001^{\mathrm{c}}$ \\
\hline \multirow[t]{2}{*}{ Color $\mathrm{a}^{\star}$} & 1 & $0.64 \pm 0.02^{\mathrm{a}}$ & $0.66 \pm 0.02^{\mathrm{a}}$ & $0.55 \pm 0.03^{\mathrm{b}}$ & $0.58 \pm 0.02^{\mathrm{b}}$ & $0.56 \pm 0.01^{\mathrm{b}}$ & $0.52 \pm 0.03^{b}$ & $0.75 \pm 0.00^{\mathrm{a}}$ \\
\hline & 28 & $0.62 \pm 0.01^{\mathrm{a}}$ & $0.62 \pm 0.01^{\mathrm{a}}$ & $0.57 \pm 0.02^{\mathrm{b}}$ & $0.61 \pm 0.03^{\mathrm{a}}$ & $0.54 \pm 0.00^{\mathrm{b}}$ & $0.49 \pm 0.00^{\mathrm{b}}$ & $0.68 \pm 0.03^{\mathrm{a}}$ \\
\hline \multirow[t]{2}{*}{ Color $b^{*}$} & 1 & $17.00 \pm 0.12^{\mathrm{b}}$ & $16.89 \pm 0.13^{\mathrm{b}}$ & $17.46 \pm 0.12^{\mathrm{b}}$ & $17.10 \pm 0.10^{\mathrm{b}}$ & $18.10 \pm 0.12^{\mathrm{a}}$ & $18.08 \pm 0.14^{\mathrm{a}}$ & $18.68 \pm 0.15^{\mathrm{a}}$ \\
\hline & 28 & $17.02 \pm 0.11^{\mathrm{b}}$ & $16.98 \pm 0.10^{\mathrm{b}}$ & $17.53 \pm 0.11^{\mathrm{b}}$ & $17.30 \pm 0.12^{\mathrm{b}}$ & $18.33 \pm 0.13^{\mathrm{a}}$ & $18.16 \pm 0.11^{\mathrm{a}}$ & $18.79 \pm 0.17^{\mathrm{a}}$ \\
\hline
\end{tabular}

The results are the means of three batches analyzed in triplicate \pm standard deviation. Results on the same row with different superscript letters differ significantly ( $\mathrm{p} \leq 0.05$ ) according to Tukey's test.

No syneresis (data not shown) occurred during the 28 days of storage, which shows the positive effect of the gums employed in the formulations. In addition, the incorporation of the cheese whey generated in the protein coagulation step in the cream cheese formulations did not affect syneresis.

From the $\mathrm{pH}$ values measured during the cream cheese formulation process, it was possible to calculate the kinetic parameters of acidification, as shown in Table 4.

Among the formulations with only one type of milk, the maximum rate of acidification was higher for cream cheese made with goat milk and lower for the product made with buffalo milk, probably because of the buffering effect characteristic of acid-base compounds from goat, cow and buffalo milk (Ahmad et al., 2008; Medeiros et al., 2015).

Table 5 shows the results of the texture profile of the different cream cheese formulations at 1 day after manufacture.

Miri \& Habibi Najafi (2011) evaluated cream cheese and found that the hardness increased as the lipid content increased, which was also seen in samples CC3, CC5, and CC7 of this study. The highest moisture content should result in a soft consistency, and this was observed in the CC1 (58.37\%), CC2 (58.57\%), CC4 (58.83\%), and CC6 formulations (60.05\%), which had the highest moisture content and consequently the lowest hardness.

Tunick (2000) defines adhesion as the work required to overcome the pulling force between the cheese and the surface of the probe used. In this work, the adhesion ranged from -577.12 to $-122.11 \mathrm{~g} \cdot s$, indicating a great adhesion of cream cheese
Table 4. Kinetic parameters of acidification evaluated during the elaboration of cream cheese.

\begin{tabular}{cccc}
\hline Formulations & $\mathrm{V}_{\max }\left(\mathrm{x} 10^{-3} \mathrm{upH}_{\mathrm{min}}^{-1}\right)$ & $\mathrm{T} \mathrm{V}_{\max }(\mathrm{h})$ & $\mathrm{pH} \mathrm{V}_{\max }$ \\
\hline CC1 & 4.9 & 4.5 & 5.13 \\
$\mathrm{CC} 2$ & 5.4 & 3.5 & 5.28 \\
$\mathrm{CC} 3$ & 4.5 & 4.0 & 5.30 \\
CC4 & 3.9 & 6.5 & 5.01 \\
CC5 & 4.1 & 5.5 & 5.18 \\
CC6 & 3.4 & 6.5 & 5.07 \\
CC7 & 3.7 & 6.5 & 4.96 \\
\hline
\end{tabular}

$\mathrm{V}_{\max }=$ maximum rate of acidification; $\mathrm{T} \mathrm{V}_{\max }=$ time in hours to reach the maximum rate of acidification; $\mathrm{pH} \mathrm{V}_{\max }=\mathrm{pH}$ corresponding to the maximum rate of acidification.

Table 5. Results of the texture analysis of the cream cheese formulations at 1 day after manufacture.

\begin{tabular}{cccc}
\hline Formulations & Hardness $(\mathrm{g})$ & Adhesion $(\mathrm{g} \cdot \mathrm{s})$ & Elasticity $(\mathrm{mm})$ \\
\hline CC1 & 157.50 & -122.11 & 2.32 \\
CC2 & 292.70 & -157.83 & 1.93 \\
CC3 & 434.60 & -187.26 & 1.10 \\
CC4 & 304.50 & -464.80 & 0.70 \\
CC5 & 575.10 & -577.12 & 0.61 \\
CC6 & 311.50 & -130.08 & 1.90 \\
CC7 & 534.90 & -245.73 & 1.03 \\
\hline
\end{tabular}

to the probe and consequently to the teeth of the consumer. Thus, it is possible to classify this product as having high moisture.

Another evaluated rheological parameter was the elasticity of cream cheese, which is the tendency of the material to recover its 
original shape after applied tension (Fox et al., 1998). The elasticity of cream cheese varied between 0.61 and $2.32 \mathrm{~mm}$, and samples with lower lipid contents had lower values of elasticity.

\subsection{Lactic acid bacteria counts of cream cheese formulations}

Figure 1 shows the evolution of lactic acid bacteria counts present in cream cheese formulations over the 28 days of storage.

The lactic acid bacteria evaluated in the formulations of cream cheese tended to grow until the $14^{\text {th }}$ day of storage, after which the number of viable cells decreased considerably. The L. acidophilus count ranged from 5.08 to $7.85 \mathrm{log} \mathrm{CFU} \cdot \mathrm{g}^{-1}$ on cream cheese per day after manufacture, and a decrease in the counts of this microorganism was observed in most formulations, which may have been related to antagonism induced by elevated S. thermophilus (Dave \& Shah, 1997). This antagonism can be observed in Figure 1, in which most formulations have a higher number of viable cells for the starter culture (S. thermophilus) and, consequently, a lower count of probiotic microorganisms (B. lactis and L. acidophilus) during the period of analysis.

The B. lactis count varied from 4.32 to $7.48 \mathrm{log} \mathrm{CFU} \cdot \mathrm{g}^{-1}$ over 28 days of storage, the maximum value being similar to that observed by Cardarelli et al. (2008) for their petit Suisse probiotic cheeses (7.40 to $7.69 \log$ CFU.g ${ }^{-1}$ ). According to Slačanac et al. (2010), the milk includes minerals such as calcium, zinc and magnesium, which, like the high protein content, are important for the complex of enzymes involved in the fermentation of lactose, thus favoring the multiplication of bifidobacteria. This was evidenced in formulation CC3 (buffalo milk), which had the highest protein content due to the milk used in its elaboration and therefore presented the greatest multiplication of bifidobacteria at 28 days of storage.

For a food to be considered probiotic, the product must have a minimum concentration of viable microorganisms between $10^{8}$ and $10^{9} \mathrm{CFU}_{\mathrm{g}}{ }^{-1}$ (Brasil, 2002). Considering the counts of Lactobacillus acidophilus and Bifidobacterium lactis, two probiotic microorganisms present in the cream cheese composition, the developed product can be considered a functional food. At 14 days, CC4 and CC7 were the formulations that presented the highest microbial counts, and at 28 days of storage, the highest cellular concentrations were in the $\mathrm{CC} 7$ formulation, followed by CC1 .

\subsection{Sensory characteristics of cream cheese formulations}

Table 6 presents the sensory evaluation of cream cheese formulations made with milk of different origins and at 1 day after manufacture.
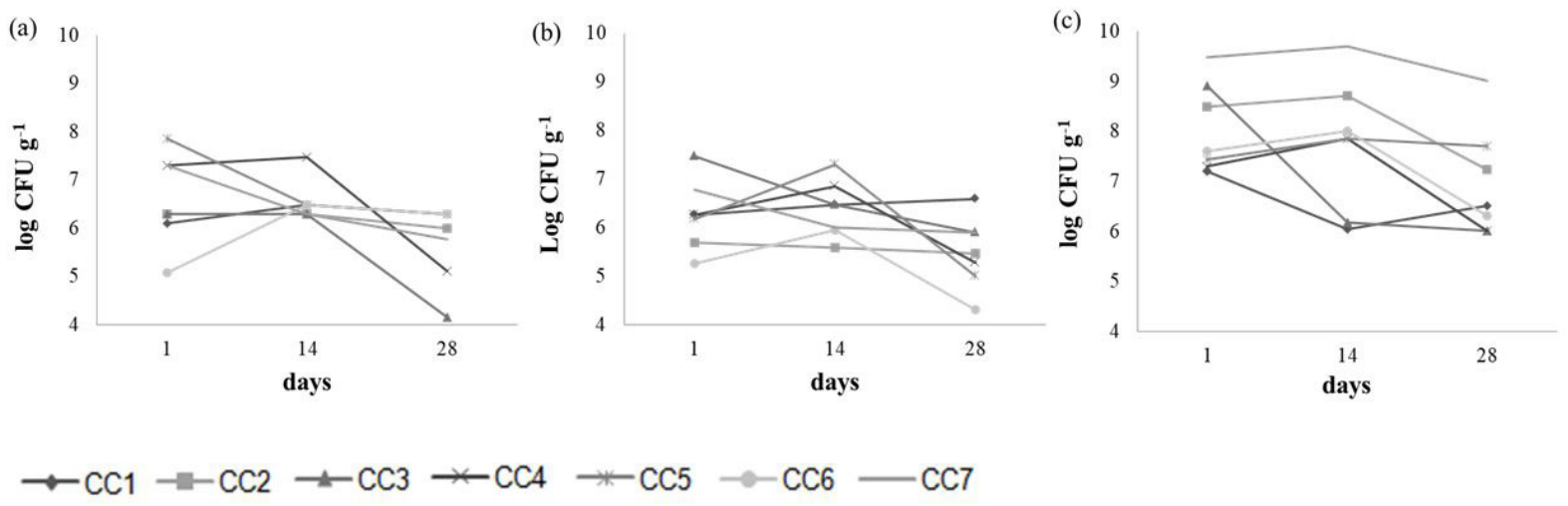

Figure 1. Lactic acid bacteria count (log CFU.g $\left.{ }^{-1}\right)$ during the 28 days of storage of cream cheese formulations made from milk of different origins. (a) Lactobacillus acidophilus; (b) Bifidobacterium lactis; (c) Streptococcus thermophilus.

Table 6. Mean sensory results and acceptability indices of cream cheese samples made from milk of different origins and at 1 day after manufacture.

\begin{tabular}{|c|c|c|c|c|c|c|c|}
\hline \multirow{2}{*}{ Attribute } & \multicolumn{6}{|c|}{ Formulations } & \multirow[b]{2}{*}{ CC7 } \\
\hline & $\mathrm{CC} 1$ & $\mathrm{CC} 2$ & $\mathrm{CC} 3$ & CC4 & CC5 & CC6 & \\
\hline Appearance & $\begin{array}{c}7.32 \pm 1.33^{\mathrm{a}} \\
{[81.33]}\end{array}$ & $\begin{array}{c}7.10 \pm 1.36^{\mathrm{a}} \\
{[78.89]}\end{array}$ & $\begin{array}{c}7.06 \pm 1.45^{\mathrm{a}} \\
{[78.44]}\end{array}$ & $\begin{array}{c}7.16 \pm 1.50^{\mathrm{a}} \\
{[79.56]}\end{array}$ & $\begin{array}{c}7.08 \pm 1.54^{\mathrm{a}} \\
{[78.67]}\end{array}$ & $\begin{array}{c}6.64 \pm 1.57^{\mathrm{b}} \\
{[73.78]}\end{array}$ & $\begin{array}{c}7.20 \pm 1.41^{2} \\
{[80.00]}\end{array}$ \\
\hline Odor & $\begin{array}{c}7.12 \pm 1.15^{\mathrm{a}} \\
{[79.11]}\end{array}$ & $\begin{array}{c}6.94 \pm 1.58^{\mathrm{a}} \\
{[77.11]}\end{array}$ & $\begin{array}{c}7.04 \pm 1.50^{\mathrm{a}} \\
{[78.22]}\end{array}$ & $\begin{array}{c}6.98 \pm 1.54^{\mathrm{a}} \\
{[77.56]}\end{array}$ & $\begin{array}{c}6.78 \pm 1.62^{\mathrm{a}} \\
{[75.33]}\end{array}$ & $\begin{array}{c}6.54 \pm 1.61^{\mathrm{a}} \\
{[72.67]}\end{array}$ & $\begin{array}{c}7.10 \pm 1.43^{2} \\
{[78.89]}\end{array}$ \\
\hline Flavor & $\begin{array}{c}6.50 \pm 1.91^{\mathrm{a}} \\
{[72.22]}\end{array}$ & $\begin{array}{c}6.32 \pm 1.92^{\mathrm{a}} \\
{[70.22]}\end{array}$ & $\begin{array}{c}6.58 \pm 1.87^{\mathrm{a}} \\
{[73.11]}\end{array}$ & $\begin{array}{c}6.44 \pm 2.16^{\mathrm{a}} \\
{[71.56]}\end{array}$ & $\begin{array}{c}6.64 \pm 1.73^{\mathrm{a}} \\
{[73.78]}\end{array}$ & $\begin{array}{c}6.24 \pm 1.65^{\mathrm{a}} \\
{[70.01]}\end{array}$ & $\begin{array}{c}6.84 \pm 1.89^{2} \\
{[76.00]}\end{array}$ \\
\hline Texture & $\begin{array}{c}6.82 \pm 1.65^{\mathrm{a}} \\
{[75.78]}\end{array}$ & $\begin{array}{c}6.82 \pm 1.45^{\mathrm{a}} \\
{[75.78]}\end{array}$ & $\begin{array}{c}6.96 \pm 1.55^{\mathrm{a}} \\
{[77.33]}\end{array}$ & $\begin{array}{c}7.06 \pm 1.78^{\mathrm{a}} \\
{[78.44]}\end{array}$ & $\begin{array}{c}6.92 \pm 1.65^{\mathrm{a}} \\
{[76.89]}\end{array}$ & $\begin{array}{c}6.44 \pm 1.74^{\mathrm{a}} \\
{[71.56]}\end{array}$ & $\begin{array}{c}6.82 \pm 1.72 \\
{[75.78]}\end{array}$ \\
\hline Overall Impression & $\begin{array}{c}7.04 \pm 1.54^{\mathrm{a}} \\
{[78.22]}\end{array}$ & $\begin{array}{c}6.90 \pm 1.36^{\mathrm{a}} \\
{[76.67]}\end{array}$ & $\begin{array}{c}6.94 \pm 1.58^{\mathrm{a}} \\
{[77.11]}\end{array}$ & $\begin{array}{c}6.92 \pm 1.64^{\mathrm{a}} \\
{[76.89]}\end{array}$ & $\begin{array}{c}6.90 \pm 1.59^{\mathrm{a}} \\
{[76.67]}\end{array}$ & $\begin{array}{c}6.62 \pm 1.58^{\mathrm{a}} \\
{[73.56]}\end{array}$ & $\begin{array}{c}7.06 \pm 1.73 \\
{[78.44]}\end{array}$ \\
\hline
\end{tabular}

Results are expressed as the mean of the scores \pm standard deviation, followed by the acceptability index in brackets, represented as a percentage. Results in the same row with different superscript letters differ significantly $(\mathrm{p} \leq 0.05)$ according to Tukey’s test. 
The results of the cream cheese sensory analysis were satisfactory, as the scores were higher than 6.00 and the AI was above $70 \%$ for all formulations and attributes. For most of the evaluated parameters, despite the use of different types of milk in the cream cheese formulations, no significant differences were observed between the formulations, which may have been related to the lack of cream cheese consumption habit. The best score was given to the appearance of formulation CC1 (7.32), made only with cow milk. The lowest score was given to the taste of formulation CC6 (6.24), made with goat milk and buffalo milk. Of the evaluated attributes, appearance and odor had the highest mean scores across formulations.

The CC1 sample, made of cow milk (58\%), and CC7, made of cow milk, goat milk and buffalo milk (60\%), obtained the highest frequencies of positive intent to purchase ("would certainly buy" and "would possibly buy"), and $32 \%$ of respondents "would certainly buy" the CC7 sample. The best acceptability index for overall impression was also for the CC7 sample (78.44\%), and its attributes obtained scores between 6.82 and 7.20. Similar results (6.23 to 7.72) were observed by Garcia et al. (2008) for the acceptability of cheese curds from buffalo, goat and cow milk.

\section{Conclusions}

The cream cheese formulation elaborated only with buffalo milk (CC3) presented higher values of lipids, ashes, proteins, and water activity. There was an inverse relationship between the moisture and lipid contents of the samples. The acidity increased three times during the storage period of 28 days, and no formulation showed syneresis. Regarding the microbiological features, the evaluated microorganism showed development up to 14 days of storage, after which cell concentrations decreased. Regarding sensory analysis, all formulations were considered satisfactory, and the acceptability index was higher than $70 \%$ for all evaluated attributes of the seven formulations elaborated. Formulation $\mathrm{CC} 1$ had the best appearance. For the formulations $\mathrm{CC} 1$ and $\mathrm{CC} 7$, the purchase intent was higher, and the CC7 formulation presented better acceptability.

\section{Acknowledgements}

The authors thank Languiru Dairy Products (Laticínios Languiru; Teutônia/RS/Brazil) for the donation of cow milk and goat milk, Kronhardt Dairy Products (Laticínios Kronhardt; Glorinha/RS/Brazil) for the donation of buffalo milk, Bremil for allowing tests with the texturometer for the analyses, and the University of Vale do Taquari (Universidade do Vale do Taquari - Univates) for financial support.

\section{References}

Ahmad, S., Gaucher, I., Rousseau, F., Beaucher, E., Piot, M., Grongnet, J. F., \& Gaucheron, F. (2008). Effects of acidification on physicalchemical characteristics of buffalo milk: a comparison with cow's milk. Food Chemistry, 106(1), 11-17. http://dx.doi.org/10.1016/j. foodchem.2007.04.021

Aichinger, P. A., Michel, M., Servais, C., Dillmann, M. L., Rouvet, M., D’Amico, N., Zink, R., Klostermeyer, H., \& Horne, D. S. (2003). Fermentation of a skim milk concentrate with Streptococcus thermophilus and chymosin: structure, viscoelasticity and syneresis of gels. Colloids and Surfaces B: Biointerfaces, 31(1), 243-255. http:// dx.doi.org/10.1016/S0927-7765(03)00144-9.

Álvarez, S., Rodríguez, V., Ruiz, M. E., \& Fresno, M. (2007). Correlaciones de textura y color instrumental con la composición química de quesos de cabra canarios. Archivos de Zootecnia, 56(1), 663-666.

Appels, L., Baeyens, J., Degrève, J., \& Dewil, R. (2008). Principles and potential of the anaerobic digestion of waste-activated sludge. Progress in Energy and Combustion Science, 34(6), 755-781. http:// dx.doi.org/10.1016/j.pecs.2008.06.002.

Barlowska, J., Szwajkowska, M., Litwinczuk, Z., \& Król, J. (2011). Nutritional value and technological suitability of milk from various animal species used for dairy production. Comprehensive Reviews in Food Science and Food Safety, 10(6), 291-302. http://dx.doi. org/10.1111/j.1541-4337.2011.00163.x.

Blaschek, K. M., Wendorff, W. L., \& Rankin, S. A. (2007). Survey of salty and sweet whey composition from various cheese plants in Wisconsin. Journal of Dairy Science, 90(4), 2029-2034. http://dx.doi. org/10.3168/jds.2006-770. PMid:17369245.

Brasil, Ministério da Saúde. Agência Nacional de Vigilância Sanitária - ANVISA. (2002, January 9). Aprova o regulamento técnico de substâncias bioativas e probióticos isolados com alegação de propriedades funcional e ou de saúde (Resolução RDC n ${ }^{\circ}$, de 7 de janeiro de 2002). Diário Oficial [da] República Federativa do Brasil.

Brasil, Ministério da Agricultura, Pecuária e do Abastecimento - MAPA, Secretaria de Defesa Agropecuária. (2006, December 14). Oficializa métodos analíticos oficiais físico-químicos, para controle de leite e produtos lácteos (Instrução normativa ${ }^{\circ} 68$ de 12 de dezembro de 2006). Diário Oficial [da] República Federativa do Brasil.

Buriti, F. C. A., Rocha, J. S., Assis, E. G., \& Saad, S. M. I. (2005). Probiotic potential of Minas fresh cheese prepared with the addition of Lactobacillus paracasei. Lebensmittel-Wissenschaft + Technologie, 38(2), 173-180. http://dx.doi.org/10.1016/j.lwt.2004.05.012.

Cardarelli, H. R., Buriti, F. C. A., Castro, I. A., \& Saad, S. M. I. (2008). Inulin and oligofructose improve sensory quality and increase the probiotic viable count in potentially synbiotic petit-suisse cheese. Lebensmittel-Wissenschaft + Technologie, 41(6), 1037-1046. http:// dx.doi.org/10.1016/j.lwt.2007.07.001.

Ceballos, L. S., Morales, E. R., De la Torre Adarve, G., Castro, J. D., Martínez, L. P., \& Sampelayo, M. R. S. (2009). Composition of goat and cow milk produced under similar conditions and analyzed by identical methodology. Journal of Food Composition and Analysis, 22(4), 322-329. http://dx.doi.org/10.1016/j.jfca.2008.10.020.

Claeys, W. L., Verraes, C., Cardoen, S., De Block, J., Huyghebaert, A., Raes, K., Dewettinck, K., \& Herman, L. (2014). Consumption of raw or heated milk from different species: an evaluation of the nutritional and potential health benefits. Food Control, 42, 188-201. http://dx.doi.org/10.1016/j.foodcont.2014.01.045.

Coelho, K. O., Machado, P. F., Coldebella, A., Cassoli, L. D., \& Corassin, C. H. (2004). Determination of the physical-chemical pattern of buffalo milk samples using automatic analyzers. Ciência Animal Brasileira, 5(3), 167-170.

Commission Internationale de l'Eclairage - CIE. (1996). Colourimetry (2nd ed.). Vienna: CIE Publication.

D’Alessandro, W. T. (1991). Teor de proteína do leite de cabras Parda Alpina e Anglo-nubiana. In Anais da 28ª Reunião Anual da Sociedade Brasileira de Zootecnia. Viçosa: SBZ.

Dave, R. I., \& Shah, N. P. (1997). Viability of yoghurt and probiotic bacteria in yoghurts made from commercial starter cultures. 
International Dairy Journal, 7(1), 31-41. http://dx.doi.org/10.1016/ S0958-6946(96)00046-5.

De Wit, J. N. (2001). Lecturer's handbook on whey and whey products. Brussels: European Whey Products Association.

Dutcosky, S. D. (1996). Análise sensorial de alimentos. Curitiba: Champagnat.

Food and Drug Administration - FDA. (2017a). CFR: Code of Federal Regulations Title 21: chapter I: Food and Drug Administration Department of Health and Human Services, subchapter B-food for human consumption. Silver Spring: FDA. Retrieved from https:// www.accessdata.fda.gov/scripts/cdrh/cfdocs/cfcfr/CFRSearch. $\mathrm{cfm}$ ?fr $=131.110$

Food and Drug Administration - FDA. (2017b). CFR: Code of Federal Regulations Title 21: food and drugs, chapter I: Food and Drug Administration Department of Health and Human Services Subchapter, $L$ - regulations under certain other acts administered by the Food and Drug Administration. Silver Spring: FDA. Retrieved from https://www.accessdata.fda.gov/scripts/cdrh/cfdocs/cfcfr/ CFRSearch.cfm?fr $=1240.3$

Fox, P. F., McSweeney, P. L. H., Cogan, T. M., \& Guinee, T. P. (1998). Fundamentals of cheese science. Gaithersburg: Aspen.

Garcia, R. V., Falcão, R. S. Fo., Duarte, T. F., Pessoa, T. R. B., Queiroga, R. C. R. E., \& Moreira, R. T. (2008). Acceptability and sensory preference of cheese curds elaborated with female buffalo, goat and cow milk. Revista do Instituto de Laticínios Cândido Tostes, 363(63), 12-16.

Guo, H. Y., Pang, K., Zhang, X. Y., Zhao, L., Chen, S. W., Dong, M. L., \& Ren, F. Z. (2007). Composition, physicochemical properties, nitrogen fraction distribution, and amino acid profile of donkey milk. Journal of Dairy Science, 90(4), 1635-1643. http://dx.doi. org/10.3168/jds.2006-600. PMid:17369203.

Instituto Adolfo Lutz - IAL. (2008). Normas analíticas: métodos químicos e físicos para análise de alimentos (4. ed.). São Paulo: IAL.

Lara-Villoslada, F., Olivares, M., \& Xaus, J. (2005). The balance between caseins and whey proteins in cow's milk determines its allergenicity. Journal of Dairy Science, 88(5), 1654-1660. http://dx.doi.org/10.3168/ jds.S0022-0302(05)72837-X. PMid:15829656.

Leitner, G., Merin, U., \& Silanikove, N. (2004). Changes in milk composition as affected by subclinical mastitis in goats. Journal of Dairy Science, 87(6), 1719-1726. http://dx.doi.org/10.3168/jds. S0022-0302(04)73325-1. PMid:15453484.

Mahmood, A., \& Usman, S. (2010). A comparative study on the physicochemical parameters of milk samples collected from buffalo, cow, goat and sheep of Gujrat, Pakistan. Pakistan Journal of Nutrition, 9(12), 1192-1197. http://dx.doi.org/10.3923/pjn.2010.1192.1197.

Medeiros, A. C., Souza, D. F., \& Correia, R. T. P. (2015). Effect of incubation temperature, heat treatment and milk source on the yoghurt kinetic acidification. International Food Research Journal, 22(3), 1030-1036.

Minim, V. P. R. (2012). Análise sensorial: estudos com consumidores. Viçosa: Editora UFV.

Miri, M. A., \& Habibi Najafi, M. B. (2011). The effect of adding enzymemodified cheese on sensory and texture properties of low- and high-fat cream cheeses. International Journal of Dairy Technology, 64(1), 92-98. http://dx.doi.org/10.1111/j.1471-0307.2010.00624.x.

Montgomery, D. C. (2001). Design and analysis of experiments. New York: John Wiley \& Sons.

Pellegrini, L. G., Gusso, A. P., Cassanego, D. B., Mattanna, P., \& Silva, S. V. (2012). Características físico-químicas e cor instrumental de ricota fresca de leite de cabra. Synergismus Scyentifica, 7(1), 1-3.

Phadungath, C. (2005). Cream cheese products: a review. Songklanakarin Journal of Science and Technology, 27(1), 191-199.

Queiroga, R. C. R. E., Santos, B. M., Gomes, A. M. P., Monteiro, M. J., Teixeira, S. M., Souza, E. L., Pereira, C. J. D., \& Pintado, M. M. E. (2013). Nutritional, textural and sensory properties of Coalho cheese made of goats', cows' milk and their mixture. LebensmittelWissenschaft + Technologie, 50(2), 538-544. http://dx.doi.org/10.1016/j. lwt.2012.08.011.

Ramunno, L., Cosenza, G., Pappalardo, M., Longobardi, E., Gallo, D., Pastore, N., Di Gregorio, P., \& Rando, A. (2001). Characterization of two new alleles at the goat CSN1S2 locus. Animal Genetics, 32(5), 264-268. http://dx.doi.org/10.1046/j.1365-2052.2001.00786.x. PMid:11683712.

Slačanac, V., Božanić, R., Hardi, J., Rezessyné Szabó, J., Lučan, M., \& Krstanović, V. (2010). Nutritional and therapeutic value of fermented caprine milk. International Journal of Dairy Technology, 63(2), 171189. http://dx.doi.org/10.1111/j.1471-0307.2010.00575.x.

Souza, V. R., Carneiro, J. D. S., Pinto, S. M., Souza, A. B., \& Stephani, R. (2012). Effect of concentration of fat in the physical, chemical and sensory petit suisse cheese produced with retention of serum. Revista do Instituto de Latícinios Cândido Tostes, 386(67), 20-28. http://dx.doi.org/10.5935/2238-6416.20120032.

Tunick, M. H. (2000). Rheology of dairy foods that gel, stretch, and fracture. Journal of Dairy Science, 83(8), 1892-1898. http://dx.doi. org/10.3168/jds.S0022-0302(00)75062-4. PMid:10984168.

Venetsaneas, N., Antonopoulou, G., Stamatelatou, K., Kornaros, M., \& Lyberatos, G. (2009). Using cheese whey for hydrogen and methane generation in a two-stage continuous process with alternative $\mathrm{pH}$ controlling approaches. Bioresource Technology, 100(15), 3713-3717. http://dx.doi.org/10.1016/j.biortech.2009.01.025. PMid:19231170.

Vinderola, C. G., \& Reinheimer, J. A. (1999). Culture media for the enumeration of Bifidobacterium bifidum and Lactobacillus acidophilus in the presence of yoghurt bacteria. International Dairy Journal, 9(8), 497-505. http://dx.doi.org/10.1016/S0958-6946(99)00120-X.

Vinderola, C. G., Prosello, W., Ghiberto, T. D., \& Reinheimer, J. A. (2000). Viability of probiotic (Bifidobacterium, Lactobacillus acidophilus and Lactobacillus casei) and nonprobiotic microflora in Argentinian Fresco cheese. Journal of Dairy Science, 83(9), 1905-1911. http:// dx.doi.org/10.3168/jds.S0022-0302(00)75065-X. PMid:11003217.

Zicarelli, L. (2004). Buffalo milk: its properties, dairy yield and mozzarella production. Veterinary Research Communications, 28(1, Suppl 1), 127-135. http://dx.doi.org/10.1023/B:VERC.0000045390.81982.4d. PMid:15372941. 